\title{
Teaching The Portrait of a Lady as a Tale of Two Travelers
}

\section{Amy Muse}

University of St. Thomas (MN)

\section{A Vindication of the Right to Teach Henry James}

It was barely dawn outside my office windows as I read David Yaffe's "Why I Still Teach Portrait of a Lady" in the Chronicle of Higher Education. Yes, Henry James's novel is long and dense and painstakingly, even painfully, nuanced and "nineteen out of 20 students may not even get it," but Yaffe stubbornly persists because

teaching The Portrait of a Lady is a reminder of all the barriers that are in the way of one's idea of freedom, whether it's 1881 or 2012. I see male and female versions of Isabel Archer every time I teach the book, and I want them to be aware of what is before them, even if I know that it will probably not make a difference. They have to experience the expanse of youth before it is narrowed as the years roll in. At best, this narrowing is called focus. At worst, it is confinement.

"Precisely," I said to the computer screen, squeezing my paper takeout coffee cup with righteous fervor. The previous spring I had assigned The Portrait of a Lady for a senior seminar entitled "English Majors in the World." Its lofty goal transcending the university-prescribed learning objectives was to achieve just this kind of open-horizon-holding: inspiration and practical tools for students to create international and intercultural lives post-graduation, even if they remained in Minnesota. I had seen too many seniors, anxious about the job market, too easily let their lives get narrowed and shuttered into convention in that last year of college, hobbling them for several years or, I fear, for life.

To that horizon-stretching end, we read Peter Hessler's River Town about teaching English in China and corresponded via email with alumni from our program who had been teaching English in Vietnam and Prague. We read literature created out of human rights work done at and with and by nonprofit organizations: listening to the stories of a Sudanese refugee in the U.S. (Dave Eggers' What is the What) and women victimized by war in Bosnia (Eve Ensler's Necessary Targets), and studied the creation processes of those works (Eggers' and Ensler's methods, draft versions, and reflections on the hopes for, and ethical and political dilemmas of, their projects). As a boost of you-can-do-this-too reassurance, alongside these professional works, we read a documentary drama created by one of my former students from her work with women in a homeless shelter in St. Paul. To spur the envisioning of specific locales for their dreams, and practice the all-important art of grant-writing to get them there, they wrote mock-applications for Fulbright scholarships. All of these assignments met with

success; some students were more interested in one than another, as always, but the value of what they were to learn and its applicability to work they might do in the world as English majors was clear. 
The Portrait of a Lady, however, my lead-off text, my seminar foundation-the quintessential study abroad novel, no?-flopped. Sure, the students struggled with James's demanding prose, but I expected that. It was as they floundered with the accompanying essay assignment that I realized I had cast us into current debates in the field of education abroad: what conditions and assignments produce the best learning experiences? I taught The Portrait of a Lady because it was the novel that spoke to my own experience, nearly 30 years earlier, of studying abroad in England and Paris and was, I thought, the perfect novel with which to begin a semester preparing English majors for possible learning opportunities if not a whole life abroad. It wasn't so much the mere travel that takes place within the storyline but the "drama of the perceiving mind" (Gorra 311) that James presents us with in his heroine, Isabel Archer, which mattered to me. If the most important outcome of education abroad is intellectual development, we must attend to what happens to students' consciousness and, therefore, The Portrait of a Lady, despite its seemingly old-fashioned setting and plot, still benefits American students venturing out into the world. End of story.

What my students' reading showed me was that most of them wanted a different kind of experience abroad. They weren't critical of their home customs and weren't ready to shuffle them off for European culture. For that matter, it wasn't even Europe they wanted to visit; southeast Asia, South America, Africa were far more enticing and, what's more, places where they could see themselves making a difference and being personally transformed. ${ }^{1}$ Europe was old, known, beatenpath, set in its ways, complacent; Eastern Europe might do. They resisted the character of Isabel Archer, whom they found cold, rigid, opaque, unfriendly, incomprehensible and, in the end, foolish. Instead, nearly all cottoned to Henrietta Stackpole, Isabel's journalist friend from New York. When I read the novel as a young traveller I found Henrietta merely a comic foil. Yet as I've reread her, especially through my students' eyes, I've softened into sharing the view of William Dean Howells, editor and friend of James's, who wrote, "we may be quite sure that Mr. James does not like the peculiar phase of our civilization typified in Henrietta Stackpole; but he treats her with such an exquisite justice that he lets us like her" (24). Henrietta is an entirely different traveller from Isabel; turning our attention to her alongside Isabel instead of dismissing her outright complicates the narrative of studying abroad. Reading The Portrait of a Lady as a tale of two travelers allows it to remain the quintessential study abroad novel. Just not in the way I once thought it was.

\section{A Tale of the American Abroad}

For readers who could use a refresher, The Portrait of a Lady is the story of Isabel Archer, a young American woman brought to England by her expatriate aunt. Epitomizing the American Abroad, what Isabel desires most in the world is independence, autonomy, the freedom to choose her destiny. ("I don't wish to be a mere sheep in the flock; I wish to choose my fate," she declares [169].) Although she is eager to learn the customs of the country, to know what is considered gauche or acceptable, this is not so as to follow the customs blindly, but "so as to choose" when and how she will (70). From the moment of Isabel's arrival in England she is wooed by the suitors we'd expect from a romance novel or Jane Austen film adaptation: the driven and strapping American mill-owner Caspar Goodwood, who pursues her to Europe; the genial and courtly, wears-his-extraordinarywealth-lightly Lord Warburton; and, in a more Platonic fashion, her own kindred spirit, her 
tubercular cousin Ralph Touchett. It is Ralph who urges his dying father to leave Isabel an inheritance, a large one, intended to set her free, to "put a little wind in her sails" (191). Instead, she becomes prey to fortune hunters, and the novel climaxes midway with her spectacularly bad decision to marry another American expatriate, an art collector named Gilbert Osmond, an exhibition of cosmopolitanism gone wrong. ${ }^{2}$ It is clear to us and to everyone except Isabel that the man she chooses, Osmond, wants her only for her money and will squeeze the life out of her. (Among the many ominous hints we're given is Osmond's cool assessment of Isabel's "one fault"; "She has too many ideas" [299].)

Osmond has a teenage daughter, Pansy, whom he keeps locked away in a convent school, infantilized and terrified of making a decision for herself. He has a mysterious relationship with another American expatriate who goes by the name of Madame Merle; it is only late in the novel that Isabel discovers Pansy is the issue of an adulterous liaison between Osmond and Madame Merle. Isabel strives to help Pansy find some independence and marry the man she loves, Ned Rosier. (Yes, another American expatriate; they all find each other, which is itself a commentary on the life of the American abroad. Why is there almost no intermingling with the locals?) If there's any sliver of happiness to be found in the ambiguous ending of the novel, in which Isabel (having temporarily fled her now irrefutably vile marriage to be with Ralph in his final days) states she will return to Rome, it is with the hope that she is going to help Pansy.

Oh, wait, what about Henrietta Stackpole, you ask? Right. I could sketch the arc of this novel without ever mentioning Henrietta. Not fair, perhaps, but true. That's why in all my previous readings it was easy to overlook her. Not that she's a minor character in terms of page-time; she gets plenty of that. Henrietta has been a friend of Isabel's since shortly before her father's death, whose "courage, energy, and good-humour" (54) Isabel much admires. With ambitions to be "queen of American journalism" (174) Henrietta has traveled to Europe to produce chatty travel pieces on specimens of Englishness and her path intersects with Isabel not just through friendship but because Isabel can give her access to English lords and landowners whom she wants to interview. Unlike Isabel, Henrietta has worked for whatever money she has; what's more, "without parents and without property" she adopted three of her "infirm and widowed" sister's children and put them through school. She is the loyal but bossy, butt-kicking friend who fights to help her imaginative chum keep from living too much in the world of her dreams and find some contact with reality (226). Her primary role in the plot is conspirer with Caspar Goodwood to get him to wherever Isabel will be so that he can continue to press his suit. A staunch patriot ("if you marry one of these people," she declares to Isabel, "I will never speak to you again! [172]), she is drawn by James with an uncharacteristic lack of subtlety as a stereotypical American, all bustling action and no introspection, all earnestness and no wit, strictly literal with no penchant for irony. ${ }^{3}$ James doesn't give her an inner life. He does, however, give her a nice ironic twist in the end. While Isabel is stuck with an evil American expatriate who suffocates her spirit (and whom Henrietta urges her to divorce), Henrietta, despite all earlier protests, gets a marriage with an Englishman, the jolly Robert Bantling, and a life in London. She gets, in other words, the recognizably happy ending. For all that, it's easy to view Henrietta as merely the low plot to Isabel's high plot, the comic relief to Isabel's tragedy. 


\section{Telling the Story of Your Experience}

On campus or abroad, my favorite and most effective writing assignments are the ones in which students tell the story of their experience, whether of travel or reading. Unlike transactional writing assignments that ask them to objectively record what they did or saw on their excursion or what the plot of the book is, they are instructed to track through descriptive, reflective, self-conscious writing how the text or site affects them: what happens to their minds and bodies and perhaps hearts and souls as well. ${ }^{4}$ In his study In Ruins: A Journey through History, Art, and Literature Christopher Woodward refers to this as the difference between seeing as a poet and seeing as an archaeologist (28). To encourage them to see as poets, I ask students to produce a subjective rendering of the text or site. Rather than pretending that they are not even present in the reading or viewing, acting as though their presence is irrelevant to the experience, they acknowledge their presence. They describe the phenomenon of experiencing. Doing so well necessitates that they not fly off into some poetic ether that ignores what's before them; instead, it requires close attention to the thing itself as well as fine attunement to their encounter with it.

Henry James is the master of such subjective renderings and Isabel Archer one of his most celebrated portraits. Indeed, William Dean Howells called The Portrait of a Lady an "analytic study rather than a story" (24) and with this in mind I gave seminar participants the task of tracking their responses to Isabel throughout the novel's twists and turns and unfoldings. Because the course is a capstone seminar in which students are expected to reflect back upon their disciplinary learning of the past four years and look ahead to their futures, they were to track their responses as English majors and as young Americans heading out into the world. That is, they were to read for matters of form and style (drawing upon their prior learning about the genre of the novel, effects of free indirect discourse narration, theories of reading) and for content about travel and a young person's life choices (taking note of the novel's views of Americans in Europe, Isabel's fierce desire for independence, the challenges that are placed before her and the decisions she makes). When they found themselves delighted or stirred or perturbed, they were to reflect on what, precisely, triggered that response: a particular word, the change in rhythm or pace of the narration, an image that recalled a past event or reading experience. This is my failproof assignment, my go-to; once students adjust themselves to such finely-grained observation and introspection they find the assignment meaningful and memorable. But this time? Assuming that my students would see themselves in Isabel Archer was my big mistake. The lone male in the dozen, a passive observer himself, identified with his mirror image Ralph Touchett, so I approved his request to track a response to Ralph instead. A couple, surprisingly, somewhat disturbingly, saw themselves as Pansy, the fettered daughter of Gilbert Osmond and Madame Merle, never allowed to have her own mind. OK, I murmured, you can track responses to Pansy, then. One (one!) student, the mini-me who had just returned from a semester at the University of Edinburgh, ardently took to the assignment and claimed an allegiance to Isabel. The others petitioned for Henrietta Stackpole. I was outnumbered. I had to give in. And to figure out what was going on. 


\section{A Tale of Two Travelers}

The presence of so many Henrietta-trackers in the room made me shift my perspective of the novel from a single-person study to a comparative portrait of learners abroad. Travel is a way of making yourself, stepping out of the Ugg boots and North Face jackets, or whatever the uniform is at your school, and discovering potential new selves. And The Portrait of a Lady had always seemed like a "study abroad novel" to me because our first layer of information about her so pointedly presents Isabel as the very kind of student who heads right to the study abroad office upon arriving on campus. Her brother-in-law comments that "Isabel is written in a foreign tongue. [. . .] She ought to marry an Armenian, or a Portuguese" (31). Her sister agrees: "she ought to go abroad. She's just the person to go abroad" as it will give her "a chance to develop" (31). This is Isabel's wish as well; "she had a desire to leave the past behind her and, as she said to herself, to begin afresh" (32). What she loved most was "to feel the continuity between the movements of her own heart and the agitations of the world" (35); she has a "great fondness for intervals of solitude" (159) and prefers to wander alone, searching for the self she might become. (Indeed, she's out of place among her compatriots at home: "her reputation of reading a great deal hung about her like the cloudy envelope of a goddess in an epic" [33] and, so as not to rattle others, she had pretended not to be bookish.)

Throughout the novel Isabel travels restlessly in search of a transforming experience. On a solo walk across London one November she "loses her way in order to magnify her experience" and "walks in the belief that she has taken possession of London itself, but what she's really done is to take possession of her own life" (Gorra 161). With Madame Merle she embarks on a pilgrimage to Greece, Turkey, and Egypt, yet "her restlessness prevailed" (James 339). We're told that she "travelled rapidly, eagerly, audaciously; she was like a thirsty person draining cup after cup" (340). Later, when her marriage is in ruins, she takes herself to the ruins of Rome because in a "world of ruins the ruin of her happiness seemed a less unnatural catastrophe" (545). As Michael Gorra puts it, "Rome may stand in her mind as a 'place where people had suffered,' but that in itself works to normalize her own trouble in a way that a setting in New York's bustling modernity would not. It gives her a language with which to understand her experience, a set of images that nothing in her own past can match; it suggests that her condition isn't some odd individual exception, but the ordinary lot of human kind" (270). In that assessment, that Rome gives her "a language with which to understand her experience," Isabel could be a poster child (or, today, website child) for the power of education abroad.

What surfaced in the side by side reading is Isabel traveling for the old world, which she is charmed by: Lord Warburton is delightful because he's "just like a novel” (James 16). In contrast, Henrietta Stackpole, emissary from the new world, travels with a fixed mindset and intentions to remain just as she is. She holds "clear-cut views on most subjects" and knows "perfectly in advance what her opinions would be" (54). A sharp critic of the English monarchy and class hierarchy, she dispenses with any romanticizing of European modes of living; one of her first sensations upon arrival was feeling "a good deal cramped" in England as if she were "not going to sympathize with the atmosphere" (88) and staying for a while makes her "care more for [her] old associations than ever" (128). When her daily tasks are finished, she has a "great sense of duty" (95), she's "of an eminently social tendency" (89) and enjoys touring as part of a group, striking up acquaintances wherever she 
goes, such as with the party of Americans from Little Rock she meets on the steamer. ("Scenery is not my department; I always need a human interest," she tells Isabel [89].) When the friends and Ralph tour the National Gallery in London Henrietta declares, "I have not a sympathy with inanimate objects" and the narrator adds that "landscapes by Turner and Assyrian bulls were a poor substitute for the literary dinner-parties at which she had hoped to meet the genius and renown of Great Britain" (147). Standing in Trafalgar Square she turns her nose up at Lord Nelson: "That's the past-I don't care about the past; I want to see some of the leading minds of the present" (147). Characterized by Isabel as "a kind of emanation of the great democracy" of the U.S. (96), when Henrietta persuades Mr. Bantling (who seems less like a suitor and more like a buddy) to travel to the U.S. she is pleased that "it had opened his eyes and shown him that England was not everything" (517). They visit Versailles together and Henrietta enjoys "that you could see the ancient régime had been swept away. There were no dukes or marquises there now; on the contrary, she remembered one day when there were five American families, all walking round" (518). Though unswerving in her American ways, Henrietta is a far more modern traveler than Isabel. She and Robert Bantling "led a life of great intimacy" when they journeyed to Paris, where they "breakfasted together, dined together, [went] to the theatre together, supped together, really in a manner quite lived together" (227). James's discretion makes him mum on whether they're friends with benefits, but there's also no hint of impropriety.

Why wouldn't a student want to see herself (or himself) in Henrietta? Hers is the travel experience they want to have: filled with fun new people, parties, free of worries, always centered in the American circle. And working, being productive, not wasting time, for Henrietta is always on the lookout for a story that she can file with the papers back home. Wouldn't that be better than traveling twitchily, not knowing what you want, encountering people far more sophisticated than you (the kind of people you'd meet in Europe), people who may not have your best interests at heart, who may, indeed, want to harm you?

And you, who are directing a study abroad program; whom would you rather have in your course? Henrietta, patriotic to the point of chauvinism, holding fast to her American values, freely dispensing criticism alongside chatter in the conversations she boldly strikes up with locals, and yet agreeable to the end, reliable, easy to have in the class? Or Isabel, dreamy, imaginative, always searching for something more, able to feel deeply: but also likely to disappear without warning, to make a rash, seemingly incomprehensible decision? Her essays would be more artfully rendered, more insightful. Henrietta's would be turned in on time.

\section{When the Pi è ce de Resistance becomes the Piece to Resist}

Although Henrietta Stackpole is painted in broad strokes she is refreshingly free of what my students called Isabel's "drama," her propensity to tear herself apart in thought. ${ }^{5}$ For the seminar assignment Henrietta was simpler to track because there was no complicated inner life to sort through, no inner life at all. Isabel and Henrietta aren't, of course, real people; they are inventions of Henry James who determined that Isabel is the leading lady and Henrietta a supporting role. It may not seem as though he leaves anything out of this hefty and minutiae-filled work, but he does; there's 
no interior to Henrietta. She isn't given a "perceiving mind." As a result she's less complicated and, paradoxically, more attractive to some readers because we're kept from the subtle details that make us all such thorny and compromised humans.

Ay, there's the rub. Perhaps students resist Isabel so strongly because they're more like her than they'd care to admit. Although, as we're frequently reminded, she's the heroine of the novel, she's a mass[?] of contradictions and James doesn't shy away from detailing her errors and delusions; flaws that are considered today, perhaps unfairly, as particularly characteristic of the Millennials.

We're told, for instance, that she is "probably very liable to the sin of self-esteem: she often surveyed with complacency the field of her own nature; she was in the habit of taking for granted, on scanty evidence, that she was right; impulsively, she often admired herself" (52). He goes on. To select a mere few from a two-page-long list of imperfections:

- Her thoughts were a tangle of vague outlines, which had never been corrected by the judgment of people who seemed to her to speak with authority.

- In matters of opinion she had had her own way, and it had led her into a thousand ridiculous zigzags.

- She had an unquenchable desire to think well of herself. She had a theory that it was only on this condition that life was worth living.

- She had a fixed determination to regard the world as a place of brightness, of free expansion, of irresistible action; she thought it would be detestable to be afraid or ashamed. She had an infinite hope that she should never do anything wrong. (52)

While this list of flaws describes many of us, it has a particularity for the young, still-forming American who has been raised on the importance of self-esteem, trusting her opinions whether informed or not, always seeing the bright side, feeling confident that she will achieve success if she projects the appearance of success. James also precisely captures qualities that college students bring to a study abroad situation: thoughts that are a tangle of vague outlines, not yet disciplined and intellectually honed; and a fear of doing anything wrong.

As much as readers may want to distance themselves from Isabel Archer, they cannot escape confronting, even stealing into, her perspective. James's narrative style sees to that. He attunes us to her through his use of the free indirect discourse made famous by Jane Austen; while the story is told by a never-identified narrator the view we enter is Isabel's. Michael Gorra describes well how this works. The narrator allows Isabel's own manner of speaking, "her vocabulary and biases and ways of understanding - to percolate through his own narration" (233) so that it feels as though we're in her mind, even though we're never given full access to Isabel's thinking as we would if she were narrating. For instance, in the following passage we are given a description of her self-involvement that moves from outside to inside. While "it often seemed to her that she thought too much about herself; you could have made her blush, any day in the year, by telling her that she was selfish. She was always planning out her own development, desiring her own perfection, observing her own progress" (James 55) and in the midst of floating about in what we would call today her privileged environs, "she often checked herself with the thought of the thousands of people who were less happy than herself-a 
thought which for the moment made her absorbing happiness appear to her a kind of immodesty. What should one do with the misery of the world in a scheme of the agreeable for oneself?" (55). However, "it must be confessed that this question never held her for long. She was too young, too impatient to live, too unacquainted with pain" (55-56). After she had gotten her life secured "she might make the unfortunate condition of others an object of special attention" (56). By this last sentence the narration has moved completely into Isabel's thoughts. The language sounds like just her; we find ourselves inside her mind. And the gentle, even affectionate, criticism by the narrator of privileged self-absorption may feel vaguely like a criticism of us.

"We have just enough distance on her to mix our sympathy with judgment," Gorra observes (233) but as close as we get, she remains forever mysterious in a way that can be exasperating. We're never invited even to peek into the inner sanctum of the other characters, so while they keep their distance they don't appear inexplicable; their surfaces are smooth. The significance for my seminar was that the students tracking responses to characters other than Isabel are kept outside of the consciousness of the novel itself. Put differently: following Henrietta forestalls difficult but indispensable inner work.

\section{Education Abroad Should be about Changing Your Consciousness}

For Henry James, "the business of writing lay not in making his characters 'do' anything, but rather in discovering a situation that would allow them to reveal themselves" (Gorra 40). That is precisely what learning abroad can, and should, offer: discovering situations, creating assignments, setting up opportunities that will allow students to reveal themselves. The Portrait of a Lady shows Isabel traveling widely, but in James's design, her true "adventures would lie not in the outward events of her life, but rather in her comprehension of them, in an inner drama that might, to her, seem as enthralling as any tale of pirates or caravans" (Gorra 69). Reading radically interior narratives and practicing rigorously introspective writing, at home and on site, can aid students in articulating their own inner events. Now, this may to some of you seem narrowly focused, even antithetical to education abroad. I am focusing on the inner life of traveling students rather than on the outward things they will see. But it is only in comprehension of their experience that we see intellectual development. In this matter location is incidental. One can be closed in Cambodia or porous in Paris.

I teach The Portrait of a Lady for students to immerse themselves, uncomfortably at times, in the winding ways of a developing young woman's consciousness, a young woman who, like it or not, shares many traits with them. It's not a life lesson I'm after. If that were the case I might reach for Daisy Miller, a text perhaps more to their liking since college students I've worked with tend to be more like Daisy Miller, that is, open and reckless, than Isabel Archer; and they could take it as a cautionary tale. (Though Daisy Miller is more than just a lesson on not walking around the Coliseum with a handsome Italian at midnight.) However, instead of killing off his heroine after the bad decision, as he did in Daisy Miller, James shows us Isabel having to learn to live with the decision she made. From that point on the book, in Gorra's words, "shifts to a minor key, less exhilarating but with a new gravity and indeed nobility, whose force increases with each chapter" (224). 
The Portrait of a Lady is a novel of being educated abroad. Its interior style forces readers to closely consider why they travel, what and whom they might encounter, how they want to live their lives. In this tale of two travelers James comes down on Isabel's side, and many of us who teach and advise students abroad may as well. But let students view these travelers in light of the decisions they'll need to make about their own travels and lives. Let them debate the merits of one traveler over another. To do that we'll need to see The Portrait of a Lady in a different light, from different angles, but first (and still, and always) we'll need to read it.

\section{Works Cited}

Bousquet, Marc. “I Don’t Like Isabel Archer.” Henry James Review 18.2 (1997): 197-199. Project Muse. Web. 21 February 2014.

Eggers, Dave. What is the What. New York: Vintage, 2007. Print.

Ensler, Eve. Necessary Targets. New York: Villard Books, 2006. Print.

Gorra, Michael. Portrait of a Novel: Henry James and the Making of an American Masterpiece. New York: Liveright Publishing Corporation, 2012. Print.

Hessler, Peter. River Town. New York: Harper Collins, 2001. Print.

Howells, William Dean. "Henry James, Jr." Century Illustsrated Magazine (Novermber 1882): 24

James, Henry. The Portrait of a Lady. 1882. New York: Penguin Classics, 2011. Print.

McMurtrie, Beth. "Is Europe Passé?" Chronicle of Higher Education (29 July 2013): Web. 22 February 2014.

Shubert, Adrian. "The Pursuit of Exotica': A Comment," Frontiers: The Interdisciplinary Journal of Study Abroad XV (Fall/Winter 2007-2008): 197-201. Web. 20 February 2015.

Wagner, Kenneth and Tony Magistrale. Writing Across Culture: An Introduction to Study Abroad and the Writing Process. New York: Peter Lang, 1995. Print.

Woodward, Christopher. In Ruins: A Journey through History, Art, and Literature. New York: Vintage, 2003. Print.

Woolf, Michael. "The Baggage They Carry: Study Abroad and the Construction of 'Europe' in the American Mind." Frontiers: The Interdisciplinary Journal of Study Abroad XXI (Fall 2011): 289309. Web. 22 February 2014.

---. "Come and See the Poor People: the Pursuit of Exotica" Frontiers: The Interdisciplinary Journal of Study Abroad XII (Fall 2006): 135-146. Web. 22 February 2014.

----. "Politics-and-Poverty Tourism: the Lure of Study in Developing Countries." Chronicle of Higher Education (13 August 2013). Web. 22 February 2014.

Yaffe, David. "Why I Still Teach Portrait of a Lady." Chronicle of Higher Education 59.8 (19 October 
2012): B20. Web. Last accessed 21 February 2014.

\section{Notes}

${ }^{1}$ This is, of course, a most timely issue itself: how important is location, in particular a new, lesstraveled, "exotic" location, to students' learning? Beth McMurtrie’s "Is Europe Passé?" in the Chronicle of Higher Education and Michael Woolf's follow-up to that, "Politics-and-Poverty Tourism," as well as his arguments in Frontiers over the years, such as "The Baggage They Carry: Study Abroad and Construction of 'Europe' in the American Mind" (XXI: Fall 2011): 289-309 and "Come and See the Poor People: The Pursuit of Exotica,” XII (Fall 2006): 135-146 (and Adrian Shubert's response to "The Pursuit of Exotica" in Frontiers XV [Fall/Winter 2007-2008]) are good places to start.

${ }^{2}$ I want to thank Martha Johnson for this most apt descriptor of Osmond.

${ }^{3}$ Marc Bousquet points out that "the self-promoting Henrietta Stackpole is a not-so-oblique reference to 'Roarin' Ralph Stackpole, one of the earliest and most enduring stage-emblems of Jacksonian heroic individualism, a boisterous, self-aggrandizing frontier hero on the order of Mike Fink the riverboat man or Mose the fireman" (197). This underscores James's intentions that she be a lightweight comic character, a sidekick rather than serious central figure.

${ }^{4}$ Kenneth Wagner and Tony Magistrale's Writing Across Culture: An Introduction to Study Abroad and the Writing Process recommends assignments of this sort under the heading of expressive writing.

${ }^{5}$ They might align themselves with Marc Bousquet, who writes "I DON'T LIKE ISABEL ARCHER. I never have liked her, and I'm always surprised when other people admire her. She seems to me selfish, naive, ill-attuned to the feelings of others despite her education, an emblem of caprice and poor judgment--at best emergently admirable at the end of the novel, after the ordeals that transform her into Mrs. Gilbert Osmond" (197). 